large districts of the earth though varying from ore region to another."

He says further:-

"If we compare the successive pressure groups with the prominence curve, it will be seen that India and south-eastern Asia are in very close synchronous agreement. This synchronism extends also to New South Wales, the Indian Ocean and even to South Africa. In Siberia and Russia, the synchronism begins to break: little and seems to be transferred somewhat towards the right, although this may be due in part to defective data. In Europe and in the United States, while the same curve is developed as to the number of the maxima and minima, the synchronism becomes more irregular. In South America, on the other hand, the synchronism is resumed very distinctly, but the entire curve is reversed as referred to India and the Eastern Hemisphere. Thus we perceive that around the Indian Ocean the synchronism is clearly developed; it weakens in Europe and North America, and it becomes a distinct reversal in South America ..."

From the above, it will be seen that Prof. Bigelow also demonstrates the existence of large areas which are in excess and in defect of pressure simultaneously, while others are not in such close synchronism.

It may here be mentioned that he treats North America as a whole and gives a curve showing the short period variation, of pressure. It is of interest, however, to note, as has been shown earlier in this article, that the southern

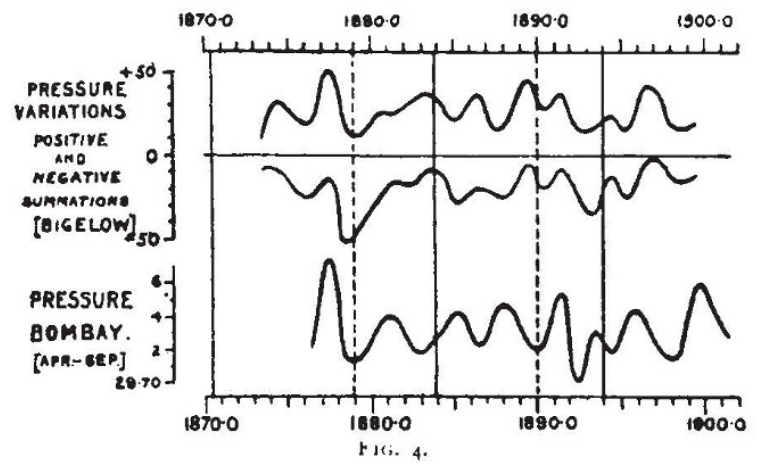

part of the United States, as represented by stations shown in Fig. 3 , is in very close agreement with Cordoba, while it is the inore northern parts and Canada where the synchronism more apparently begins to break.

At the conclusion of his paper, Prof. Bigelow makes a summation of all those areas which give positive and negative values respectively for the pressure variations, and the curves of these are reproduced here (Fig. 4) with a slight change to make the scale homogeneous with others reproduced in this article. The Bombay pressurè curve has also been added, and a smooth curve is drawn through the points instead of connecting them with straight lines as in Fig. 2.

The parallelism of the two upper curves indicates, as Prof. Bigelow points out, that "the values do not cancel each other," and that as "the curves match fairly well with the prominence curve, ... I take it to mean that some external force is at work to raise and lower the total atmospheric pressure by a small amount from vear to year."

'The two investigations are in agreement as regards the following three main points. First, the close connection between solar activity and barometric pressure ; second, the great extent of areas over which very similar pressure variations exist ; and, third and last, the presence of two large areas the pressure variations over which are the reciprocal of each other.

$$
\text { NO. I } 732 \text {, VOL. } 67]
$$

It is interesting to remark that, from the comparisons of the pressure variations over the different areas, the authors of both these investigations were led to consider whether these suggestive features were connected with the idea of a periodical see-saw of pressure extend ing over a few years between these two nearly antipodal areas, or whether we were in presence of a barometric wave travelling round the earth.

There seems little doubt that when more facts are collected these reciprocal pressure variations will in time play an important part in forecasting the general features of seasons and thus supply meteorologists with another means of helping them in their difficult task.

The value that must in future be placed on observations of the sun which inform us of his state of activity or quiescence, since these pressure variations are apparently so closely connected with them, cannot any longer be laid on one side, but must be recognised as of a high order of importance.

WILIIAM J. S. LOCKYER.

EDUCATION IN GERMANY AND ENGLAND. $\mathrm{M}$ ANY people in this country, eminent men of science and literature, leading men in commerce and industry, and politicians who place efficiency before party shibboleths, have for many years felt apprehensive as to the condition of our national system of education. For a long time, they have been speaking and writing upon the subject and endeavouring-by pointing to advancements and achievements of other nations who have put their educational house in order-tu stir up the nation at large to realise the enormous interests which are at stake. For many years, the warnings fell upon deaf ears and the advocates of reform were either looked upon as bores or cranks. To-day all this is changed, and it is almost unfashionable not at least to talk about education; this does not, however, necessarily imply a knowledge of the subject.

Were it not for its terrible prolixity, those who really desire to know the ins and outs of the German educational system could not do better than carefully study vol. ix. of "Special Reports on Educational Subjects," dealing with Germany, which is issued by the Board of Education. A mere glance at this report shows that, although the present system of education in Germany has been of such incalculable value to the Empire, yet those interested in education in that country-and their name is legion-are questioning whether their system is after all so good as it might be. There are many in Germany who think that some of our freedom from restraint would give a breadth of idea and a broadness of horizon which is not obtained by their methods of abstract reasoning and rigid exactness.

The report embraces primary, secondary and technical education. The first 200 pages consist of dissertations by different writers upon different aspects or phases of education. The first of these is by Mr. M. E. Sadier, who has compiled the report, upon "The Unrest in Secondary Education in Germany and Elsewhere." This also includes a comparison between English and German methods. Mr. Sadler admits at once that we have an insufficiency of good secondary day schools and that education at our public schools is not what it should be. Further, our technical training is defective, and, owing to our comparative neglect of national education for many years past, "as a nation we are much less intelligently interested than the Germans in methods of instruction." It is true that German and French methods are now very much advocated in this country, but the great difficulty is that those who desire us indiscriminately to imitate and introduce curricula and methods from other nations seem totally unable to realise that if we wish for an exact copy, we must at the same time reproduce the social and economic conditions of these other countries. 
The old idea in England was, teach a boy to be manly, teach him not to be a sneak and a coward, and at the same time give him a smattering of education, then let him be placed in the Army or Navy or business and, come what may, character will carry him through. There is no doubt about it that our public-school life, with its traditions and the esprit de corps which it engenders, has had much to do with moulding character, and in past generations, when other nations were settling their internecine troubles and it was simply a question of staking out claims for posterity, this style of education was satisfactory enough. But Germany and other nations, as soon as they had settled their internal struggles, proceeded at once to build up a system of national education which has had far-reaching effects upon many of their most important industries. Not only has German education had such enormous influence upon their own industries, owing to the introduction of scientific methods, but it has likewise been felt in this country, because our manufacturers and traders, not having been taught to believe in scientific training, have stuck to old-time methods, with the disastrous result that in many branches of industry we are unable to compete with the scientific German. In Prussia, all the secondary schools are upon the same lines. The Prussian knows the meaning of a secondary school; it would puzzle an Englishman to define one. The standard is practically the same in all the Prussian secondary schools; here we have no standard at all. English masters as a rule are devoted to their schools, German masters to education. An English boy loves his school; a German boy has not the same feeling of esprit de corps, but looks upon his school as an establishment for obtaining knowledge. We lay stress on character, the Germans on knowledge. There are good points in each. The tendency in our schuols to make the school standard one of proficiency in sport, and to make fun of earnestness and to chaff those who desire to obtain knowledge, is not good. That objectionable expression "don't talk chop," which is often hurled at the head of those who, through a sincere interest in their business or profession, wish to exchange ideas with others, is the outcome of this characteristic. On the other hand, the Germans would undoubtedly gain if they had more freedom from restraint and were not so bound down by hard and fast rules and regulations.

Other nations have realised that an education which was sufficient fifty years ago is antiquated and of little value in the present day, when science and learning have made suth enormous strides. In matters of educational reform, or of accepting new views or theories, we have, as a nation, always shown a conservative spirit. When learning was only advancing slowly and new theories were propounded which had very little found ation of fact to rest upon, doubtless a conservative and cautious policy led in the long run to greater solidarity and was better than being too hasty in taking up new ideas solely because they were new, but which would almost immediately require to be discarded for some newer theory. But now, since the growth of knowledge, resting, as it does, on a broad foundation of experimental fact, is so rapid, it is absolutely essential that we should alter our methods in order to keep abreast of the times.

Fifty years ago, a boy might spend the bulk of his time upon the study of classics and yet be fitted to take his place in business or commerce. To-day, classics alone are of little use. Here it should be pointed out that in Germany the study of classics is not neglected; indeed, considerable stress is laid upon that study. Science is, as a rule, not taught until the boys have at least obtained a thorough general grounding in classics, and there are those in Germany who would make the classical education more thorough than it is at present. The following instance illustrates how thorough, in No. 1732 , vOL. 67 ] general, the study of Latin in Germany must be. An Englishman, a friend of the writer's, went to study in Bavaria and had no knowledge of the German language. A nephew of his landlady, a boy of about fifteen, was studying at a public secondary school, and although the Englishman was unable to make his landlady understand his wants, he was able by means of Latin to converse with her nephew and so have his urants attended to.

In a Prussian secondary school, a master has to know a great deal more of the subject which he has to teach than an English master in a similar position. In England, erudition is considered of far less importance than activity of mind and body and success in sport. We often say, "All work and no play makes Jack a dull boy"; we seem to forget the converse, that much play and little or no work unfits the boy for the struggle in after life. On p. 215 of the report, we find the following quotation from the remarks of a Frenchman :- "A boy at an English public school has qualities which a French schoolboy does not possess, but those qualities are moral and not intellectual. In English education there is a very weak point - and that is instruction." An educational system in which the weak point is instruction surely requires overhauling.

The object in our schools should be to teach that the most lasting form of pleasure is to be found in work well done. R. L. Stevenson once said, "I know what pleasure is, for I have done good work." It has been stated that one of the reasons why the Americans are so successful in the present day and seem to be carrying all before them is that "they find their pleasure in their business."

Centralisation is the backbone of the German and French educational systems. Here we have found that centralisation spells red tape, and now with the swing of the pendulum the cry is for decentralisation. Wholesale decentralisation will probably spell chaos. It is essential that we should have a satisfactory primary education, to be followed up by an efficient and carefully planned scheme of secondary education, but it is very doubtful whether the carrying out of even the finest imaginable system of education could be left entirely to the local authorities or to the teachers themselves. It would not be satisfactory to bind down teachers to a hard and fast interpretation of any code or system. Scope must be left for individuality, not, however, for eccentricity.

There is one thing the report makes abundantly clear, and that is that we have much to learn from the Germans; there are many things we might adapt, but very little that we could copy. There is a tremendous outcry in this country for specialisation, and many advocate early specialisation. Early specialisation is not at all believed in on the continent. In the continental university or polytechnic, specialisation is not allowed until a scholar is able to show that he has a thorough general education. We ought to have some equivalent to the German "Abiturienten," or leaving examination. Unless such an examination has been successfully passed, the student cannot enter a university or polytechnic and take his degree or diploma. Further, in obtaining situations in business houses, preference is invariably given to those who have successfully passed this examination; indeed, many business houses will not take men into their employment who have not passed this satisfactorily.

Sixty-five pages of the report are devoted to the "Measurement of Mental Fatigue." We find that the systematic study of mental fatigue has been taken up in a spirit of earnest, scientific inquiry; and it is worthy of note that post-mortem examinations have shown "that those parts of the brain which serve the purpose of systematic thought, commonly known as the reasoning powers, are the last to mature." The question of what constitutes mental fatigue must always be one of great difficulty. If the laws of hygiene are obeyed 
and the subject is sufficiently clothed and fed, he will probably be able to accomplish a very much larger amount of mental work, without being over-strained, than would be the case if these conditions were neglected.

In Germany, the question of dealing with over brain work is probably more pressing than it is in this country, because the brain is often over-exercised, while there is an insufficiency of physical exercise. In England, I am afraid, it is more often a question of physical fatigue than one of mental strain with which we are faced. But of course, when the teaching system is "unintelligent"that is, one of cram-the poor brain must get terribly wearied.

Mr. Sadler has compiled the report with great care, and the portions which he has himself written are marked by a refreshing breadth of view not always to be found in Governinent reports. It is probable, however, that the object would be better attained if these reports were more condensed.

F. MOLLWO PERKIN.

\section{TIDAL CURRENTS IN THE GULF OF ST. LAWRENCE.}

FOR many years past, the Canadian Goyernment has been prosecuting an accurate survey of the complicated tides and tidal currents of the Gulf of St. Lawrence. The Tidal Department, under the able directorship of Mr. W. Bell Dawson, has already done much excellent work in this field, although, doubtless, much yet remains to be discovered. In the tidal report for the present year, Mr. Dawson will describe the results of a careful analysis of the remarkable tidal currents which are met with in Northumberland Strait south of Prince Edward's Island. At most places, the times of the changes of tidal currents bear a more or less constant relationship to the times of high and low water, but in this channel the changes are found to be largely governed by the moon's declination. As Mr. Dawson remarks:- "This is very confusing to the mariner, as the turn of the current in relation to the tide is out of accord with the moon's phases, and has thus no fixed relation to the spring and neap tides. The greatest apparent irregularity is when the moon's declination it at its maximum; and this occurs sometimes at the spring tides and sometimes at the neaps. The ordinary navigator takes refuge in the conclusion that the currents are chiefly influenced by the wind."

Diurnal tides are ruled by the declination of the moon, and it would seem that there must be at this place a large diurnal inequality which manifests itself more by current than by variations of height.

Those who are interested in this subject will do well to refer to Mr. Dawson's forthcoming report.

$$
\text { G. H. D. }
$$

\section{JOHANNES WISLICENUS.}

THE generation that laid the foundation of organic chemistry has almost become a thing of the past, and at the close of last year one of the few remaining links was broken by the death of Wislicenus.

Not long since, the University of Leipzig was mourning the loss, at a venerable age, of a distinguished physicist; to-day the chair which was made famous by that "wahre Bearbeiter" Kolbe is vacant, and a name which will ever be illustrious in the history of spacial chemistry has been added to the classical traditions of this great seat of learning.

The news has come not as a sudden shock, for of late years the health of the venerable Geheimrath has been visibly declining, and waning strength and feeble gart warned his many friends that his working days would soon be over; none the less poignant, however, is the grief felt by all who have had the privilege of sharing his friendship or coming under the influence of his impressive and genial personality.

ohannes Wislicenus was born on June 24, 1835, at Klein-Eichsted, in the Prussian province of Saxony when he was five years old, his father, a pastor, was transferred to Halle a. Salle, and there the boy received his first impressions of school life. At the "Frankesche Stiftung," a school which has since become celebrated, he remained until the age of eighteen, and at Easter, 1853 , having passed his Maturitätsexamen, he entered the University of $\mathrm{Halle}$ with the intention of devoting himself to the study of natural science. His project was, however, soon frustrated. The political horizon was still clouded over, and in consequence of certain intrigues, his father, in the autumn of the same year, was compelled to fly the country; he found a home for himself and his family, as did so many refugees of that time, in the United States. In the following year, Johannes was appointed assistant to Prof. Horsford at Harvard University, Mass., and in 1855 became lecturer at the Mechanics' Institute, New York, with a laboratory at his disposal.

It was thus that he acquired that command of English which was such a source of wonder to his foreign students in later years.

In 1856 , he was able to return to Europe, and resumed his interrupted studies at the University of Zurich, where he "promovierte" in 1860 and was appointed Privat. docent at the Polytechnic.

In $186 \mathrm{r}$, he became professor of chemistry and mineralogy at the "Kantonale Industrieschule." Four vears later, he received the honour of a chair at the University of Zurich, and in 1871 was elected by the "Bundesrath" as director of the Polytechnic in that town. In the following year, he was chosen to succeed Ad. Strecker at Würzburg. There he remained until $\mathrm{J} 885$, and it was during this time that he carried on his classical researches on the constitution of acetoacetic ether and so established his reputation on a firm basis.

The year 1884 witnessed the death of Kolbe and the call of Wislicenus to Leipzig, where he remained until the end. As was pointed out by a writer recently in this Journal, "there is a curious irony in the thought that his first work there should have been directed towards the extension of the theory of Van 't Hoff, whom Kolbe had regarded with such contempt."

Of his scientific work, space will only permit the barest outline. His researches were confined almost exclusively to the domain of organic chemistry, most of them appearing in Liebiy's Annalen der Chemie. The constitution of lactic acid, on which he worked from 1863 to 1872 , establishing the identity of structure for the two different substances fermentation- and para-lactic acids, first brought him into prominence among chemical workers and impelled him to seek an explanation of the metamerism in the spacial relations of the atoms within the molecule. His interest in acetoacetic ether, to which reference has already been made, resulted in a detailed investigation of its reactions and of its value as a synthetic agent; these have gone far to stimulate the study of this most interesting compound, and are of importance, if for no other reason, for the light they throw on the still open question of its constitution.

It was in Leipzig, however, that he achieved his great work. In 1887 appeared his famous mernoir, "Über die raümliche Anordnung der Atome in organischen Molekulen," to account for the phenomena of "geometrical isomerism." According to his hypothesis, which was an extension of that formulated independently by Le Bel and Van 't Hoff in 1874, "the centre of gravity of a carbon atom was regarded as situated in the centre of a tetrahedron, and its four affinities at the four corners." When two atoms were linked together, Van't Hoff, and No. 1732 , voL. 67] 